\title{
Forest management practices and the occurrence of suspended solids in rivers and streams and their influence on ichthyofauna and river ecosystems
}

\author{
Tomasz Mikołajczyk ${ }^{1^{*}}$, Przemysław Nawrocki \\ ${ }^{1}$ Expertise and Ichtiological Research Laboratory - PEBI, ul Juliusza Lea 236/9, 30-133 Krakow, Poland; ${ }^{2}$ World Wildlife FundPoland - \\ Fundacja WWF Polska, ul. Usypiskowa 1, 02-386 Warsaw, Poland \\ *Tel. +48501306003, e-mail: tomasz.mikolajczyk@salmonidae.org
}

\begin{abstract}
This article is based on a literature review and attempts to highlight the harmful effects of forest soil erosion on aquatic ecosystems with particular emphasis on ichthyofauna. We focus on the phenomena of excessive soil erosion caused by forest management practices and forest roads, subsequent sediment runoff as well as silting of watercourses and their impact on fish. Among others, the direct influence of the suspended sediments on fish reproduction, egg incubation, respiratory processes, growth and immunity, as well as indirect effects on habitat and migration are discussed. The authors' intention is to draw attention to this important and underestimated aspect of forest management in Poland. The aim of this publication is to bring about changes in the management of commercial forests that will minimize the erosion of forest soils, formation of high levels of suspended solids in rivers and in turn limit their negative impact on aquatic ecosystems.
\end{abstract}

Keywords: forest management, soil erosion, rivers, ichthyofauna

\section{Introduction}

As of December 31, 2017, over 97\% of the 9.24 million hectares of forests in Poland, after excluding the national parks and nature reserves (GUS 2018), are managed forests. Forest management work, especially timber harvesting and skidding, and also breeding and maintenance work in older tree stand age classes, not only affects the forest environment, but also comprehensively impacts elements of the natural environment: climate, water conditions, species composition of plants, fungi and animals, including the fish and fauna dependent on water. The result of such work on the aquatic environment is intensification of the erosive processes and deposition of excessive amounts of suspended solids (sediments) through watercourses to the catchment area.

Evolution has enabled aquatic organisms to adapt to life and development under conditions of a specific amount of suspended solids. Although they can survive a short period of significantly increased water turbidity as a result of heavy rainfall or thawing during certain seasons of the year, they lose out in the face of environmental changes generated by human activity. Suspended solids of anthropogenic origin (their increased amount) adversely affect aquatic organisms, causing extensive changes in habitats and aquatic organisms (Sigler et al. 1984; Ryan 1991; Bilotta, Brazier 2008; Clapcott et al. 2011), and excessive sedimentation in a riverbed reduces the water quality and deterioratesthe aquatic environment (Robinson et al. 2010; Goode et al. 2012). Increased sediment load and the siltation of watercourses are now recognised as the main factors degrading the open water environment, even more important than chemical pollution or eutrophication (USEPA 1990; Waters 1995; Walling 2006). While the runoff of suspended solids from cultivated fields and pastures is closely correlated with the occurrence of precipitation and only increases the effect of natural erosion, sediment transport and silting, the case of some human activities during forest management (skidding, transport, etc.) results in permanent or periodic occurrence of water turbidity and silting of the riverbed and banks, most often without any relation to the current meteorological and hydrological situation. The appearance of this type of pollution at an unusual time or during periods of low water levels, that is, when the suspended solid load cannot be diluted, is extremely dangerous (Photograph 1).

Received: 21.05.2019 r., accepted after revision: 12.11.2019 r. 


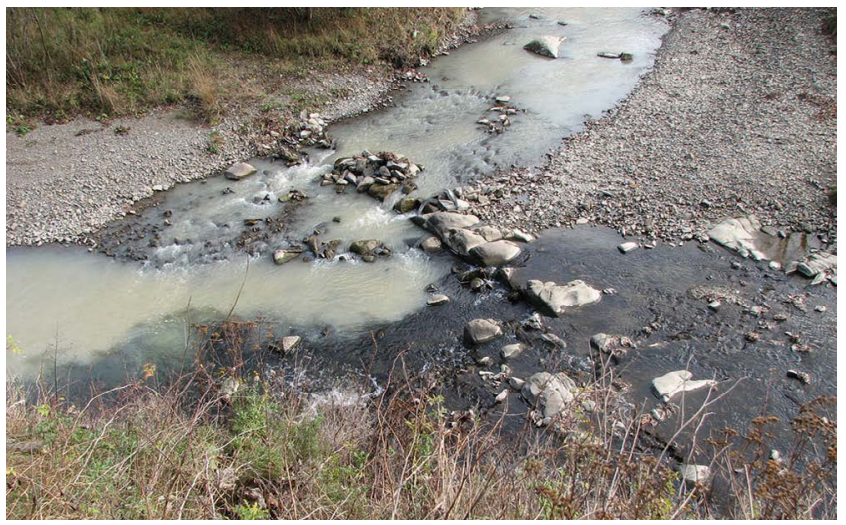

Photography 1. The mouth of the Roztoczka stream to the Solinka river. Strong turbidity of Roztoczka (in the period of low water, no rainfall) caused by logging. Photo T. Mikołajczyk

\section{Guidelines and quality parameters of water contaminated by suspended solids}

Suspended solids, that is, inorganic particles with a diameter of $0.45 \mu \mathrm{m}$ to $2 \mathrm{~mm}$ in flowing water (Clapcott et al. 2011), and the effect on nature associated with their presence are an integral part of the aquatic environment. This phenomenon is associated with the natural process of land denudation, the weathering of rocks, and water erosion and the movement of river debris. The amount and type of sediments in rivers depends on many factors such as the type of bedrock (substratum), slope and shape of the catchment, amount and type of precipitation and type of land use.

The problem of open water contamination by suspended solids was already noted in some countries several decades ago. In 1964, the European Inland Fisheries Advisory Commission to the United Nations (EIFAC 1964) identified five main ways by which fish and inland fisheries are adversely affected by an increased load of suspended solids of anthropogenic origin. These are:

- direct effects on fish in water;

- impairment of the development of fish eggs and larvae;

- modifications in the movements and migratory behaviours of fish;

- destruction of the food supply and

- preventing or impairing fishing and other fisheries management activities.

In the same document, the Commission proposed the following water quality criteria for the protection and conservation of natural resources and fisheries by defining the levels of suspended sediment:

1. $<25 \mathrm{ppm}$-lack of evidence of a negative impact of such a concentration of suspended particulate matter on fisheries;

2. $25-80 \mathrm{ppm}$ - borderline conditions for the maintenance of good or sufficient conditions for fisheries;
3. $80-400 \mathrm{ppm}$ - very difficult conditions for operating fisheries and

4. $>400 \mathrm{ppm}$ - conditions are lacking to sustain the life of fish and operate fisheries.

The EIFAC recommendations and criteria, which are based on scientific research, also apply to the concentration of sediments in the substrate that forms the bottom of watercourses. In order for lithophilous fish (those spawning on a rock and gravel bed) belonging to the Salmonidae family, as well as some species belonging to the carp family to be able to spawn without any problems, the fine sandy fraction $(<2 \mathrm{~mm})$ of the rock material forming the bottom of a stream must not exceed $10 \%$, the $<3 \mathrm{~mm}$ fraction should be $19 \%$ and the $<6.5 \mathrm{~mm}$ fraction should be less than 25\% (EIFAC 1964; Crisp 2000).

Since the publication of EIFAC (1964), the problem of increased amounts of suspended solids of anthropogenic origin and its influence on fish has been the subject of numerous studies and papers, among others, in the USA, Canada, New Zealand, Australia and Great Britain. Publications by authors such as Sigler et al. (1984), Newcombe and MacDonald (1991), Anderson (1996), Newcombe and Jensen (1996) and Caux et al. (1997) showed conclusively that the impact of sediments on organisms living in open water and water-dependent environments (coastal zone) is related to the sediment load and turbidity duration. The negative impact of these two factors is measured by the so-called "stress index", otherwise known as the pollution intensity index (Newcombe, MacDonald 1991; Newcombe 1994). The development of such an index made it possible to estimate/predict losses, for example, in ichthyofauna, after the occurrence of an increased sediment load. The model, after many modifications, is still based on the pollutant concentration and duration function and has been adapted in many countries as an official tool for research and environmental impact assessment.

\section{The impact of an increased load of suspended solids on fish}

The harmful effects of an increased load of suspended solids in flowing waters and sediments of anthropogenic origin have been described by Lloyd (1987); Newcombe, MacDonald (1991); Waters (1995); Anderson (1996); Birtwell (1999); Crisp (2000); Crowe, Hay (2004); Cavanagh et al. (2014). Its impact was considered at two levels:

- direct - on various stages of fish development (from egg to adult) and

- indirect - through its impact on the habitat, on other organisms in a trophic relationship with fish, as well as on the entire water ecosystem and transition zone (riparian zone).

Additionally, a higher suspended mineral particulate load also means changes in the chemical composition of water, changes in its $\mathrm{pH}$, temperature, as well as an increase in its nutrient content (eutrophication). 


\subsection{Direct effects}

The direct impact most often consists of the destruction of laid eggs, mechanical injuries, abrasions and damage to the integumentary system, destruction of gills, increased susceptibility to diseases and parasites and reduced growth rate. These effects are much more pronounced in the early stages of fish growth (larvae and fry).

\section{Effects on spawning and egg incubation}

The influence of sediments on the quality of spawning and reproduction of salmonids is particularly well known (Waters 1995). Fine sediments affect spawning grounds in two ways: by changing the composition of the gravel that constitutes the spawning ground (i.e. the quality of the habitat) and by changing the surface of the spawning grounds (Shirazi and Seim 1981). The concentration of fine sediments is a key factor influencing the embryonic development of salmonids (Wood and Armitage 1997). A significant increase in the concentration of particles results in reduced egg survival, increased number of prematurely hatched larvae and increased likelihood of predation occurring among the surviving juveniles. Blocking crevices in the gravel ${ }^{1}$ reduces the flow of water through the nest and impairs gas exchange, as well as hinders the removal of metabolites, slowing or stopping egg development (Furniss et al. 1991; Shirazi and Seim 1981). The oxygen concentration in water decreases even further under the influence of fine sediments rich in organic material, causing the embryos or larvae to suffocate (Bjornn and Reiser 1991), and a 10\% content of fine sediment in trout or salmon nests is already the limit for proper egg incubation and larval hatching (Crisp 2000). The diameter of the suspended mineral particles and composition of the bottom substrate play a huge role in processes affecting ichthyofauna. Shirazi and Seim (1981) defined a strong relationship between the geometric mean diameter of the substrate from which the nest is built and the percentage of embryo survival of a number of salmonid species, where embryo survival increases from $13 \%$ to $90 \%$ in a gravel diameter gradient from 5 to 20 $\mathrm{mm}$. Excessive sedimentation may also lead to its accumulation in the surface layers of the bed's substrate, its hardening and entrapment of developing eggs and hatchlings in the nest (Wood and Armitage 1997) or prevent adult fish from excavating nests (Furniss et al. 1991). The reduction in the number and size of spawning grounds leads to increased competition for suitable breeding sites (Bjornn and Reiser 1991) and may result in eggs being laid in previously formed nests or the spawning of several fish species in the same site.

${ }^{1}$ The nest of salmonid fish (e.g. brown trout) has the form of an elongated shallow cavity created by the females in the gravel bed of a brook, into which the eggs are laid, and is then covered with gravel. The key condition for proper development of the eggs in such a nest is the free flow of water between the grains of gravel.

\section{Effect on the gills and respiratory processes}

The direct harmful effects of an increased load of suspended solids on fish includemechanical damage to the outer body and gills due to the physical abrasion of the tissues by the suspended particles. This also causes the gills to be blocked by the sediments, impaired gas exchange, swollen gill filaments and hypertrophy of the epithelial cells (Sherk et al. 1973) and tissue necrosis (Servizi and Martens 1991), and ultimately death or increased susceptibility to pathogenic invasion, disease and inhibition of fishes' growth rate (Herbert and Merkens 1961; Ryan 1991; Wood and Armitage 1997). Gill damage, gill thickening and clogging most often occur at relatively high concentrations of mineral suspension ( $>500 \mathrm{mg} / \mathrm{l})$, but this lethal level may vary depending on the species or fish growth stage. Longer exposure to several times lower sediment concentrations (100 $\mathrm{mg} / \mathrm{l}$ ) almost always causes moderate gill damage (Sutherland and Meyer 2007). The harmful effect increases when the suspension is made up of sharp-edged particles.

\section{Growth}

In contrast to behavioural reactions, growth disorders as a physiological reaction are generally observed after prolonged exposure. Sigler et al. (1984) found that the growth of rainbow trout Oncorhynchus mykissfry was significantly weakened after exposure to a clay or bentonite suspension at concentrations between 84 and $120 \mathrm{mg} / 1$ during 14-21 days of exposure. Similar concentrations of suspended solids (100 mg/l or more) significantly inhibited the growth of Arctic grayling Thymallus arcticusfry (McLeay et al. 1987) and rainbow trout (Buck 1956). Another example (Sutherland and Meyer 2007) showed a significant reduction in the growth rate of two minnow species,Cyprinella galactura and Erimonax monachus, which was associated with respiratory disturbances due to contamination by suspended solids. The time within which growth disorders were observed after exposure to long-term turbidity ranged from 2 weeks for rainbow trout and Pacific salmon to 6 weeks for Arctic grayling (Sigler et al. 1984; McLeay et al. 1987).

\section{Immunity}

The presence of above-normal concentrations of mineral suspensions in water has been associated with a general decrease in the ability to defend against diseases and a reduced tolerance to chemical toxins. Herbert and Merkens (1961) observed that rainbow trout are more susceptible to fin necrosis when the fish were exposed to a $270 \mathrm{mg} / \mathrm{l}$ diatomaceous earth concentration for 121 days. Similarly, Servizi and Martens (1991) found a correlation between the incidence of viral kidney disease in Pacific salmon and increased sediment concentrations. When the mineral suspension concentrations exceeded $100 \mathrm{mg} / \mathrm{l}$, the tolerance of Arctic grayling to toxic pentachlorophenol (PCP) decreased significantly (McLeay et al. 1987). This observation usually indicates a general decrease in fish tolerance to environmental stressors. 


\subsection{Indirect effects}

Indirect effects include disruptions in the migration cycle, prevention of effective spawning, difficulties in obtaining food, changes in diet, and thus, changes in the growth rateas well as in the structure and size of fish populations of a given species.

\section{Habitat change}

The indirect influence of suspended solids and their sedimentation is manifested by changes in the habitats of ichthyofauna, located both in the river or stream itself and in the coastal zone and periodically in floodplains. The sedimentation of suspended solids and bottom silting impacts the local fish populations, in particular, by unifying the bottom structures, eliminating the hiding places and feeding sites and destroying the spawning grounds of lithophilous fish (spawning on gravel-stone beds). Experimental studies on the effect of the substrate and sedimentation on the New Zealand bully Gobiomorphus breviceps found that the density of the bully decreases significantly in response to increased sedimentation and a corresponding reduction in the surface area of the natural stony substrate (Jowett and Boustead 2001). The authors suggest that other bottom (benthic) species react similarly. These experimental results were confirmed in the field studies performed by Richardson and Jowett (2002) who discovered decreasing fish densities in the North Island streams of New Zealand with an increase in sediment load. A number of studies performed inNew Zealand suggest that the impact of sediment deposited in rivers and streams on native fish relates more to adverse habitat changes than to food availability (Richardson and Jowett 2002).

The number of salmonids (especially fry) in streams is closely correlated with the quantity and quality of the bottom substrate, consisting of gravel and stones (Bjornn and Reiser 1991; Heland 1971). Muddy and sandy substrates are of low value as the riverbed cover, especially for salmonids. Having sediments fill in the spaces around the gravel as well as in the spaces between larger substrate elements, such as boulders and stones, prevents them from being used by fish as habitats and refuges (Waters 1995). Bjornn and Reiser (1991) found that the population density of juvenile rainbow trout and salmon, both in summer and winter, was more than halved when a relatively small amount of sand was added to an experimental substrate to fill the spaces between the stones. Similarly, when sand was added to a natural stream pool, filling one-third of its depth, the fish population in this area soon decreased by two thirds.

\section{Movements and migration of fish}

Fish avoid waters (areas) polluted by an increased load of suspended solids, which affects their migration and movement (Newcombe and MacDonald 1991; Ryan 1991; Waters 1995; Wood and Armitage 1997). Changes in migration can be of par- ticular importance for the population size and species diversity of diadromous fish communities, for which the recolonisation and settlement of streams depends on successful annual migrations and effective spawning (Rowe and Dean 1998). Anthropogenic water turbidity may change the routes and destination of fish migration with all its negative consequences. Laboratory studies have shown that juvenile stages of native diadromous fish populations in New Zealand react differently to high water turbidity (Boubée et al. 1997). The species Galaxias fasciatus (endemic to New Zealand) proved to be the most sensitive to increased turbidity (already showing an avoidance reaction at a turbidity of $25 \mathrm{mg} / \mathrm{l}$ ). Other species, such as Galaxias maculatus, were less sensitive and Retropinna retropinna showed no avoidance reaction even at very high concentrations of mineral suspension (>1000 mg/l). Larger (adult) salmonids appear to tolerate the short-term effects of elevated mineral suspension concentrations, such as those occurring during heavy rainfall, better than smaller-sized salmonid fish species and juvenile stages of other species (Cordone and Kelley 1961). These researchers noted that migrating salmon also avoid waters with high suspended solid loads until migration ceases when turbidity cannot be avoided/bypassed. Thus, the migration of salmon can be significantly delayed by sediment loads occurring frequently or over a longer period of time (Bjornn and Reiser 1991).

\section{Forest management as a cause of increased soil erosion and water pollution from suspended solids}

The last few decades have been a period of dynamic development of machinery performing harvesting work in forests. The proliferation of harvesters and skidders (tractors, skidders, forwarders), often for more efficient movement in wet or sloping terrain, equipped with chains on wheels, has largely made it possible for work schedules to be carried out regardless of the weather (ground frost, moisture, etc.). What is more, the harvesting activities are conducted all year round and not, as in the past, in winter, when one was able to take advantage of the frozen ground. The presence of snow cover also mitigated the negative effects of the work on the environment. The extent of soil damage is affected not only by the type of equipment used and the type of soil, but also by the number of times the machines travel over a route, the moisture content of the ground, the time of year of the work, the distances between the timber transport routes and from the timber harvesting and storage locations (Suwała 1991; Dudek, Sosnowski 2011; Sadowski et al. 2016). Research in the United States (Bates et al. 1993) showed that skidding in summer causes $40 \%$ more damage to soil structure (number and depth of ruts) than winter skidding in the same area. Intensive forest management negatively affects water ecosystems in four basic ways (Campbell 2017): 
1. It increases soil erosion and sedimentation runoff with all the above-mentioned effects on aquatic fauna and the rivers themselves (Photograph 2).

2. It changes the chemical composition of the water in streams and brooks, increases eutrophication and the chemical pollution of water (pesticides and herbicides, oil derivatives).

3. It eliminates or drastically reduces shading of the water surface of streams and brooks, thus changing the living conditions of plants and animals, and especially increasing the water temperature, which can be lethal for cold-loving fish (salmonids, burbot, Alpine bullhead).

4. It changes the availability of woody debris in the riverbeds, essential for aquatic fauna and flora, from a drastic excess during the felling itself (bark, boughs, tree branches)

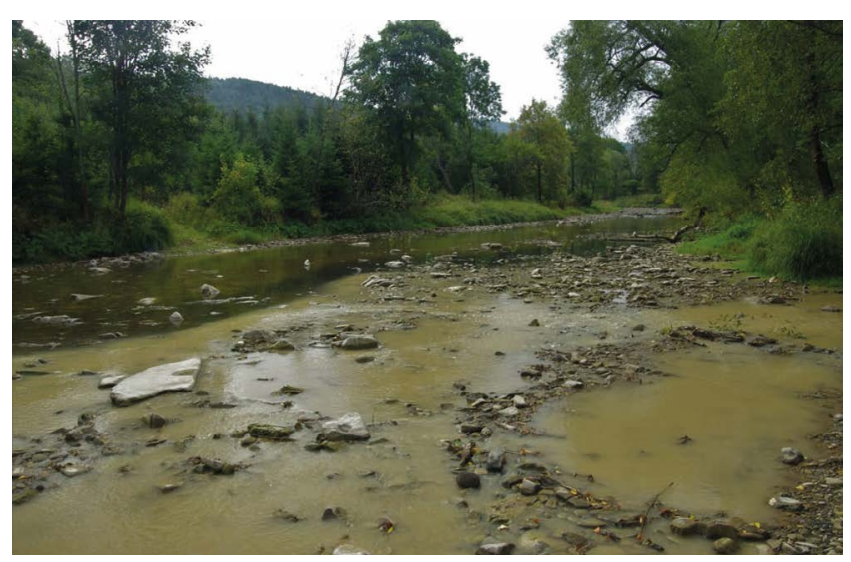

Photography 2. Strong turbidity and silting at the mouth of the nameless tributary from the logging area to the Wołosaty stream during the summer low water (no rainfall). Photo K. Kukuła

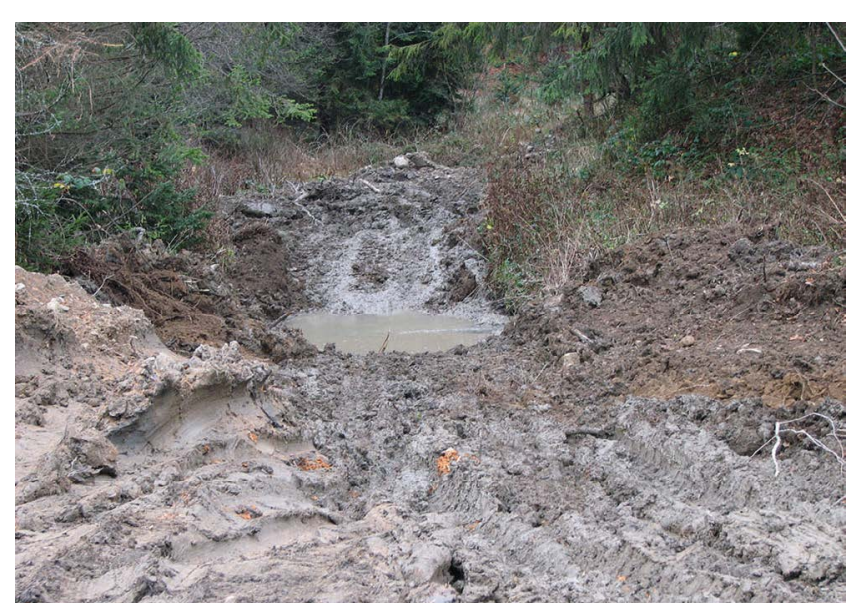

Photography 3. Crossing of the skidding trail with the Dołżyczka stream (tributary of the Solinka river) during of the low water in the autumn. Photo T. Mikołajczyk to its complete lack for many years after the felling (the growth period of saplings).

\section{Sources of suspended mineral matter in open waters}

Forestry activities may affect the hydrological system of rivers and streams by shortening the time between precipitation and the emergence of increased flow in the watercourse (reduction of catchment retention through destruction/disturbance of forest soil surfaces and removal of vegetation cover) and, consequently, increasing the height of the flood wave, increasing the sediment load, and increasing the flow rate and strength of riverbed-forming processes. Changes in the hydrological regime then cause changes in water temperature, its chemical composition and the size of the sediment load, which in turn leads to changes in the geometry of the riverbed, width and depth of the stream, and the type of bottom substrate (Meehan 1991; Salo and Cundy 1987). The sources of site erosion and sediment runoff into open waters associated with forest use include forest roads, skidding trails and timber storage areas (Anderson 1996; Grace 2005; Croke, Hairsine 2006; Anderson, Lockaby 2011). The main sources of increased sediment load are forest roads and skidding trails (Cenderholm et al. 1981; Furniss et al. 1991; Waters 1995; Brown et al. 2015). Intersections of forest roads and skidding trails with watercourses and related travel up and down slopes (Photograph 3) represent the sources of erosion with the greatest potential/danger to watercourses because of their direct hydrological contact (Lane and Sheridan 2002; Aust et al. 2011; Wear et al. 2013). Erosion also results from the use of stream channels as skidding routes, which is also often observed in Poland.

In addition, an important source of sediments associated with forest roads are landslides and mudslides, as well as the construction and maintenance of culverts, bank fortifications or

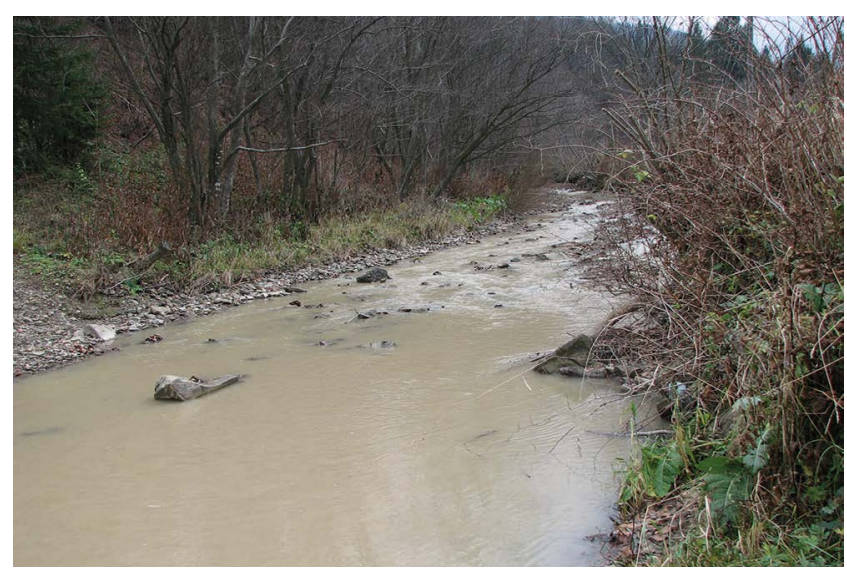

Photography 4. A completely silted Dołżyczka stream (tributary of the Solinka river), about $2 \mathrm{~km}$ below the crossing with the skidding trail (photo 3) during the low water in the autumn and during the spawning season of brown trout. Photo T. Mikołajczyk 
embankments, including earthworks (excavation) performed by heavy construction machinery, often directly in the stream bed.

The intensity of suspended mineral runoff into open waters depends on several factors such as: the intensity and nature of the precipitation, the type of soil and, above all, the slopes. Erosional processes take place most rapidly in mountain areas, precisely because of their significant land gradients as well as the greater amount of precipitation there.

In managed forest areas, most of the eroded materialsare from skidding trails and forest roads that have no plant cover and tend to have low hydraulic conductivity and little water infiltration capacity. This leads to increased surface runoff and erosion that is much higher than in the forest surrounding roads (Elliot et al. 1994a). If the forest soil permeability is about $15 \mathrm{~mm} / \mathrm{h}$ in an unused forest and the erosion runoff is 1 tonne of sediment/ha/year, the values in the forest during forestry operations are $5 \mathrm{~mm} / \mathrm{h}$ and 20 tonnes/ha/year, respectively. These same parameters for unpaved forest roads are $1 \mathrm{~mm} / \mathrm{h}$, and erosion can reach as high as 100 tonnes/ha/year (Swift 1988; Bilby et al. 1989; Eliot et al. 1994b) or up to 98 tonnes/ha/year (Brown et al. 2015). Successive scientific studies found that the sediment flow from forest roads in Idaho, USA, increased to 750 times in 6 years compared to the period before forest use. It was calculated that during this time, the average erosion rate from skidding roads was 51 to 56.2 tonnes/square mile of road/day (Megahan and Kidd 1972).

The problem of forest road erosion and its impact on the environment in Poland has not yet been analysed in detail. Dąbek and Żmuda (2011) note that forest roads are often poorly planned and poorly maintained, both during and after use, constituting a very serious source of soil erosion. They have shown significantly higher erosion from an unpaved and poorly maintained road section compared to a road section equipped with well-functioning drainage channels. Unfortunately, the authors did not present calculations that could give an idea of the amount of erosion per hectare of area and/or per kilometre of road, but they did demonstrate the significance of the problem and presented options for reducing it.

The size of the sediment flow from storage/manoeuvring yards and skidding trails inside the forest is difficult to estimate due to its very scattered and large-scale character. Skidding trails cause the greatest damage to forest soil through their movement of large masses of soil. Additional disturbances are caused by the tyres (especially those equipped with chains) of the machines, which tear and loosen the soil and then create deep ruts (Photographs 4,5), especially on slopes exceeding $20 \%$ (Eliot et al. 1994b).

\section{Summary}

Increased soil erosion caused by forest management activities, conducted without taking into account the need to protect watercourses, results in far-reaching negative effects on water ecosystems. The effects of this phenomenon are particularly visible in mountain and foothill areas, which are related to the terrain and its relief. The erosion of forest roads and skidding trails has a particularly negative impact on watercourses and all the organisms inhabiting them. The mechanisation of forest work and change in the time of harvesting and transporting wood exacerbate this effect. According to the authors, in Poland, as in many other countries of Europe and the world, there is an urgent need to give attention to this issue on the part of foresters, leading to necessary decisions to reduce or eliminate these environmentally harmful phenomena. Therefore, there is an urgent need to develop systemic and practical methods to reduce the erosion of forest soils in Poland. The experiences of countries that have already recognised and solved this problem can be useful in this respect.

\section{Conflict of interest}

The authors declare the lack of potential conflicts of interest.

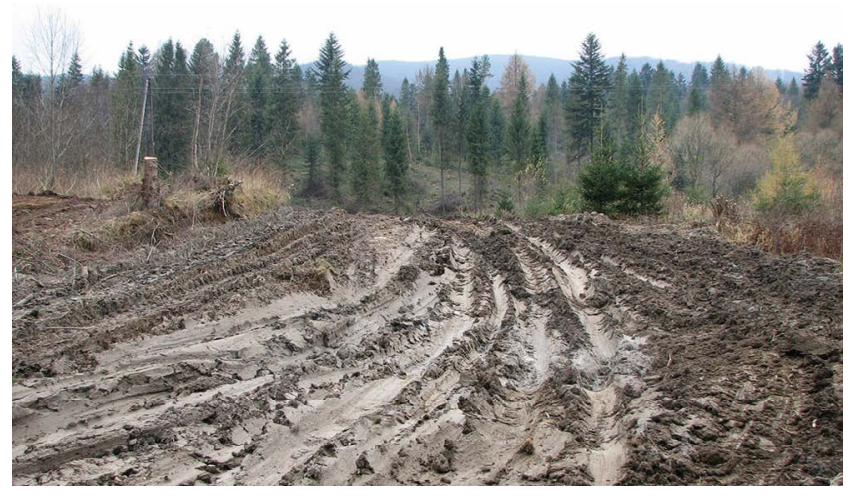

Photography 5. The skidding trail in the Cisna district on the Solinka river. Photo T. Mikołajczyk

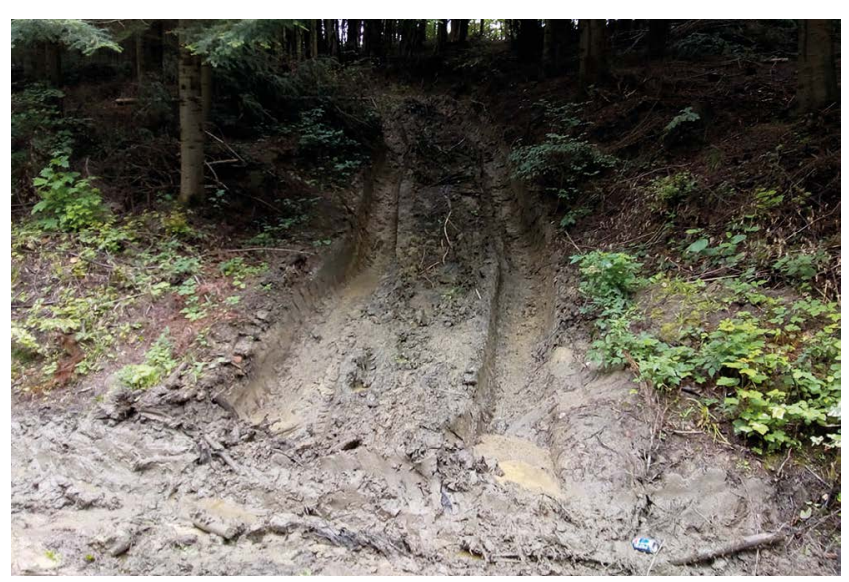

Photography 6. The skidding trail on the Witryłówka stream (Pogórze Dynowskie). Photo T. Mikołajczyk 


\section{Acknowledgements and funding sources}

The research was financed by WWF Poland Foundation and the Natural Heritage Foundation.

The authors express their gratitude to Marek Elas and Wojciech Mróz from WWF Polandand Paweł Pawlaczyk from the Naturalists Club for their valuable comments and corrections to the text.

\section{References}

Anderson P.G. 1996. Sediment generation from forestry operations and associated effects on aquatic ecosystems. Proceedings of the Forest-Fish Conference: Land Management Practices affecting Aquatic Ecosystems, May 1-4, 1996, Calgary, Alberta. DOI 10.1.1.518.5139.

Anderson C.J., Lockaby B.G. 2011. Research gaps related to forest management and stream sediment in the United States. Environmental Management 47(1): 303-313. DOI 10.1007/ s00267-010-9604-1.

Aust W.M., Carroll M.B., Bolding M.C., Dolloff C.A. 2011. Operational forest stream crossings effects on water quality in the Virginia Piedmont. South Journal of Applied Forestry 35(3): 123-130.

Bates P.C., Blinn C.R, Alm A.A. 1993. Harvesting impact on quaking aspen regeneration in northern Minnesota. Canadian Journal of Forest Research 23: 2403-2412. DOI 10.1139/x93-297.

Bilby R.E., Sullivan K., Duncan S.H. 1989. The generation and fate of road surface sediment in forested watersheds in southwestern Washington. Journal of Forest Sciences 35: 453-468. DOI 10.1093/forestscience/35.2.453.

Bilotta G.S., Brazier R.E. 2008. Understanding the influence of suspended solids on water quality and aquatic biota. Water Research 42: 2849-2861. DOI 10.1016/j.watres.2008.03.018.

Birtwell I.K. 1999. The effects of sediment on fish and their habitat. Canadian Stock Assessment Secretariat Research Document 99/139.

Bjornn T.C. Reiser D.W. 1991. Habitat requirements of salmonids stream,w: Influence of Forest and Rangeland Management on Salmonid Fishes and Their Habitats. W.R. Meehan. American Fisheries Society, Bethesda, 83-138. ISBN 978-0913235683.

Boubee J.A.T., Dean T.L., West D.W., Barrier R.F.G. 1997. Avoidance of suspended sediment by the juvenile migratory stage of six New Zealand native fish species. New Zealand Journal of Marine and Freshwater Research 31: 61-69. DOI 10.1080/00288330.1997.9516745.

Brown K.R., Aust W.M., McGuire K.J. 2015. Monitoring sediment production from forest road approaches to stream crossings in the Virginia Piedmont. Holley, Connor, Haywood eds. Proceedings of the $17^{\text {th }}$ biennial southern silvicultural research conference. E-Gen. Tech. Rep. SRS-203. Asheville, NC:U.S. Dept. of Agriculture, Forest Service, Southern Research Station, $551 \mathrm{~s}$.

Buck D.H. 1956. The effects of siltation from gold dredging on the survival of rainbow trout and eyed eggs in Powder River. Fisheries Bulletin, Oregon State Game Commission, Portland, Oregon, $3 \mathrm{~s}$.

Campbel K. 2017. Timber Industry Effect on Water pollution. https:// sciencing.com/timber-industry-effect-water-pollution-23000. html [7.05.2019].
Cederholm C.J., Reid L.M., Salo E.O. 1981. Cumulative effects of logging roads sediment on salmonid populations in the Clearwater River, Jefferson County, Washington,in: Washington Water Research Council. Proceedings from the conference on salmonspawning gravel: a renewable resource in the Pacific Northwest. Washington State University, Report 39, Pullman, 38-74.

Cavanagh J-A. E., Hogsden K.L., Harding J.S. 2014. Effects of suspended sediment on freshwater fish. RaportEnvirolink Advice Grant: 1445-WCRC129. Landcare Research ManaakiWhenua, New Zealand.

Caux P.Y., Moore D.R.J., McDonald D. 1997. Ambient water quality guidelines (criteria) for turbidity, suspended and benthic sediments: technical appendix. Prepared for the British Columbia Ministry of Environment, Lands and Parks. Water Quality Branch, Environment and Resource Management Division, Victoria, $82 \mathrm{~s}$.

Clapcott J.E., Young R.G., Harding J.S., Matthaei C.D., Quinn J.M., Death R.G. 2011. Sediment assessment methods: Protocols and guidelines for assessing the effects of deposited fine sediments on in-stream values. Nelson, Cawthorn Institute. ISBN 978-0-473-20106-7.

Cordone A.J., Kelley D.W. 1961. The influences of inorganic sediment on the aquatic life of streams. California Fish and Game 47: 189-228.

Crisp D.T. 2000. Trout and salmon: ecology, conservation and rehabilitation. Fishing New Books, Blackwell science. ISBN 0-85238-256-1.

Croke J.C., Hairsine P.B. 2006. Sediment delivery in managed forests: a review. Environmental Reviews 14: 59-87. DOI 10.1139/a05-016.

Crowe A., Hay J. 2004. Effects of fine sediments on river biota. Cawthorn Report No. 951.

Dąbek P., Żmuda R. 2011. Intensywność procesów erozji wodnej na górskich drogach leśnych. Zeszyty Problemowe Postępów Nauk Rolniczych 560: 71-78.

Dudek T., Sosnowski J. 2016. Ocena środowisko-oszczędności wybranych technologii zrywki drewna w lasach górskich. Sylwan 155(6): 413-420.

European Inland Fisheries Advisory Commission (EIFAC). 1964. Water quality criteria for European freshwater fish. Report on finely divided solids and inland fisheries. EIFAC.Food and Agriculture Organization of United Nations. Rome. EIFAC/1.21p.

Elliot W.J., Foltz R.B., Remboldt M.D. 1994a. Predicting sedimentation from roads at stream crossing with the WEPP model.ASAE International Winter Meeting. Paper no. 947511. ASAE, St. Joseph, MI, Dec 13-16.

Elliot W.J., Foltz R.B., Remboldt M.D. 1994b. A tool for estimating disturbed forest site sediment production. In Proc. Interior CedarHemlock-White Pine Forests: Ecology and Management, Spokane, WA, March 2-4 1993. Dept. of Natural Resource Science, Washington State University, 233-235.

Furniss M.J., Roelofs T.D., Yee C.S. 1991. Road construction and maintenance,in: Influence of Forest and Rangeland Management on Salmonid Fishes and Their Habitats, Edited by W.R. Meehan. American Fisheries Society, Bethesda, 297-324. ISBN 9780913235683.

Goode J.R., Luce C.H., Buffington J.M. 2012. Enhanced sediment delivery in a changing climate in semi-arid mountains basin; 
implications for water resources management and habitat in the northern Rocky Mountains. Geomorphology 139: 1-15. DOI 10.1016/j.geomorph.2011.06.021.

Grace J.M. 2005. Forest operations and water quality in the south. Transactions of the American Society of Agricultural Engineers 48: 871-880.

GUS 2018. Leśnictwo 2017.GłównyUrządStatystyczny, Warszawa.

Heland M. 1971. Influence de la densite du peuplement initial sur l'acquisition des territoires chez la truite commune Salmotrutta L. en ruisseau artificial. Annales d'Hydrobiogie 2(1) : 25-32. La truite biologie et ecologie. INRA Editions ISBN: 2-7380-0338-9

Herbert D.W.M., Merkens J.C. 1961. The effects of suspended mineral solids on the survival of trout.International Journal of Air and Water Pollution 5: 46-55.

Jowett I.G., Boustead N.C. 2001. Effects of substrate and sedimentation on the abundance of upland bullies (Gobiomorphus breviceps).New Zealand Journal of Marine and Freshwater Research 35: 605-613. DOI 10.1080/00288330.2001.9517026.

Lane P.N.J., Sheridan G.J. 2002. Impact of an unsealed forest road stream crossing: water quality and sediment sources. Hydrological Processess 16(13): 2599-2612. DOI 10.1002/hyp.1050.

Lloyd D.S. 1987.Turbidity as a water quality standard for salmonid habitats in Alaska.North American Journal of Fisheries Management 7: 34-45. DOI 10.1577/1548-8659 (1987)7<34:TAAWQS>2.0.CO;2.

McLeay D.J., Birtwell I.K., Hartman G.F., Ennis G.L. 1987. Responses of Arctic grayling (Thymallus arcticus) to acute and prolonged exposure to Yukon placer mining sediment.Canadian Journal of Fisheries and Aquatic Sciences 44: 658-673. DOI 10.1139/f87-080.

Megahan W.F., Kidd W.J. 1972.Effects of logging roads on sediment production rates in the Idaho Batholith, U.S. Forest Service Research Paper INT-123. DOI 10.5962/bhl.title.68728.

Newcomb C.P. 1994. Suspended sediments in aquatic ecosystems: ill effects as a function of concentration and duration of exposure. Habitat Protection Branch, British Columbia Ministry of Environment, Lands and Parks. Victoria, British Columbia, Canada, 298 s.

Newcombe C.P., Jensen J.O.T. 1996. Channel suspended sediment and fisheries: A synthesis for quantitative assessment of risk and impact. North American Journal of Fisheries Management 16: 693-727. DOI 10.1577/1548-8675(1996)016<0693:CSSAFA >2.3.CO;2.

Newcomb C.P., MacDonald D.D. 1991. Effects of suspended sediment on aquatic ecosystems.North American Journal of Fisheries Management 11. DOI 10.1577/1548-8675(1991)011<0072: EOSSOA $>2.3 . \mathrm{CO} ;$.

Richardson J., Jowett I.G. 2002.Effects of sediment on fish communities in East Cape streams, North Island, New Zealand.New Zealand Journal of Marine and Freshwater Research 36: 431-442. DOI 10.1080/00288330.2002.9517098.

Robinson C., Duinker P.N., Beazley K.F. 2010. A conceptual framework for understanding, assessing and mitigating ecological effects of forest roads.Environmental Reviews 18: 61-86. DOI 10.1139/A10-002.

Ryan P.A. 1991. Environmental effects of sediment on New Zealand streams: a review. New Zealand Journal of Marine and Freshwater Research 25: 207-221. DOI 10.1080/00288330.1991.9516472.
Rowe D.K., Dean T.L. 1998. Effect of turbidity on the feeding ability of the juvenile migrant stage of six New Zealand freshwater fish species.New Zealand Journal of Marine and Freshwater Research 37: 45-52. DOI 10.1080/00288330.1998.9516803.

Sadowski J., Moskalik T., Zastocki D. 2016. Ochrona gleby leśnej przy pozyskiwaniu i zrywce drewna. Studia i Materiaty CEPL w Rogowie 46(1): 173-180.

Salo E.O., Cundy T.W. eds. 1987.Streamside management: forestry and fishery interactions. University of Washington, Institute of Forest Resources Contribution 57, Seattle, Washington.

Servizi J.A., Martens D.W. 1991. Effect of temperature, season and fish size on acute lethality of suspended sediments to coho salmon (Oncorhynchus kisutch).Canadian Journal of Fisheries and Aquatic Sciences 48: 493-497. DOI 10.1139/f91-063.

Shirazi M.A., Seim W.K. 1981. Stream system evaluation with emphasis on habitat for salmonids.Water Resources Research 17: 592-594. DOI 10.1029/WR017i003p00592.

Sigler J.W., Bjornn T.C., Everest F.H., 1984. Effect of chronic turbidity on density and growth of steelheads and coho salmon. Transactions of the American Fisheries Society 113: 142-150. DOI 10.1577/1548-8659(1984)113<142:EOCTOD>2.0.CO;2.

Swift L.W. 1988. Forest Access roads: design, maintenance and soil loss,in: W.T. Swank, D.A. CrossleyJr (eds). Forest Hydrology and Ecology at Coweeta. Ecological Studies 66, Springer-Verlag, New York, 313-324. DOI 10.1007/978-1-4612-3732-7-23.

Sutherland A.B., Meyer J.L. 2007. Effects of increased suspended sediment on growth rate and gill condition of two southern Appalachian minnows. Environmental Biology of Fishes 80: 389-403. DOI 10.1007/s10641-006-9139-8.

Suwała M. 1991. Uszkodzenia drzew i gleby przy pozyskiwaniu drewna w późnych trzebieżach drzewostanów sosnowych. Prace Instytutu Badawczego Leśnictwa, Seria A: 873.

USEPA 1990. The quality of our nation's water: a summary of the 1988 National Water Quality Inventory. U.S. Environmental Protection Agency, USEPA EPA Raport 440/4-90-005, Washington, DC.

Walling D.E. 2006.Human impact on land-ocean sediment transfer by the world's river.Geomorphology 79: 192-216. DOI 10.1016/j. geomorph.2006.06.019.

Waters T. 1995. Sediment in streams: Sources, biological effects and control. Monograph 7.American Fisheries Society, Bethesda, Maryland. ISBN 978-0913235973.

Wear L.R., Aust M.W, Bolding M.C. Strahm B.D., Dolloff C.A. 2013. Effectiveness of best management practices for sediment reduction at operational forest stream crossings. Forest Ecology and Management 289(1): 551-561. DOI10.1016/j.foreco.2012.10.035.

Wood P.J., Armitage P.D. 1997. Biological effects of fine sediment in the lotic environment.Environmental Management 21: 203-217. DOI $10.1007 / \mathrm{s} 002679900019$.

\section{Authors' contribution}

T.M. - writing the text, literature review, gathering the photographic documentation; P.N. - concept of the work, corrections to the text, literature review. 